\title{
Meningkatkan Kompetensi Perpajakan Bagi Guru-Guru Akuntansi SMK Di Wilayah Jakarta Timur
}

\author{
Rubiatto Biettant ${ }^{1}$, Licke Bieattant ${ }^{2}$, Liem Yan Sugondo ${ }^{3}$, Eka Pujianthi ${ }^{4}$, Prima Dedi Andrian ${ }^{5}$, \\ Charlie $^{6}$
}

Fakultas Ekonomi dan Bisnis Universitas Trisakti, Jakarta, Indonesia $1,2,3,4,5,6$

rubybiettant@gmail.com

ARTICLE INFO

Keywords:

Community Service

(PKM) Corporate Income

$\operatorname{Tax}$

Fiscal Reconciliation

Report
ABSTRACT
Taxation as an indispensable science in society, taxation is the biggest reven in Indonesia. The need for workers who understand taxation continues increase both at the level of administrative and policy technicians. One of $t$. main competencies in accounting is taxation, because taxation is inseparak from accounting. Accounting teachers must have good competence to be able transfer their knowledge to students in their schools in an effort to produ graduates that are needed by industry. The tax training that can be deliver. this time is about the corporate income tax and fiscal reconciliation repo Community Service Activities (PKM) are carried out by a number of lecture from the Faculty of Economics and Business of Trisakti University collaboration with the Development of East Jakarta Education and Vocationa Workforce Competency Development (P2KPTK2), held for 2 (two) days on 18 19 July 2019, with participants were accounting teachers with a total of 4 people. Activities in the form of lectures and training.The results and finding of this training activity are known that this activity is very helpful for th teacher management to better understand the calculation of corporate incom tax and reporting of fiscal reconciliation reports. .

\section{A. PENDAHULUAN}

Seiring dengan pertumbuhan sebuah Negara, maka tak dapat dielakan Negara akan membutuhkan dana pembangunan yang besar untuk membiayai segala keperluannya. Pengeluaran utama negara adalah untuk pengeluaran rutin seperti biaya pegawai, subsidi, utang, bunga dan cicilannya yang dipenuhi dari penerimaan dalam negeri yang berupa penerimaan sektor migas (minyak dan gas) dan non migas (pajak dan non pajak). Pembangunan diharapkan berlandaskan pada kemampuan sendiri, sedangkan bantuan luar negeri merupakan pelengkap. Dalam membiayai pengeluaran rutin maupun pengeluaran pembangunan, salah satu yang dibutuhkan dan terpenting adalah peran serta aktif dari para warga untuk ikut memberikan iuran kepada negara dalam bentuk pajak, sehingga segala keperluan tersebut di atas dapat dibiayai.

Pajak Penghasilan $(\mathrm{PPh})$ adalah pajak yang dikenakan terhadap orang pribadi dan badan, berkenaan dengan penghasilan yang diterima atau diperoleh selama satu tahun pajak (Resmi ,2013) Pajak sebagai penerimaan negara mennjadi fokus utama pemerintah dalam upaya pembiayaan pembangunan. Berbagai kebijakan yang ditetapkan pemerintah terkait dengan perpajakan demi meningkatkan penerimaan pajak. Sunset Policy dan Tax Amnesty sebagai salah satu kebijakan yang akan diambil oleh pemerintah Direktorat Jenderal (Ditjen) Pajak Kementerian Keuangan RI dalam upaya mengejar target penerimaan pajak yang semakin meningkat setiap tahunnya. Seperti pada tahun 2015 target penerimaan pajak mencapai Rp 1.294,3 triliun, atau sekitar 72 persen dari target penerimaan negara sebesar Rp 1.793,6 triliun yang dipatok dalam Anggaran Pendapatan Belanja Negara (APBN) 2015. Dari total target sebesar Rp 1.294,3 triliun tersebut, sejumlah Rp 904,1 triliun rencananya akan diperoleh dari penerimaan rutin sedangkan sisanya sebesar Rp 390,2 triliun harus dikejar dengan upaya ekstra (extra effort). Separuh target penerimaan pajak dari extra-effort tersebut atau sekitar Rp 200 triliun diharapkan dapat dicapai melalui Sunset Policy (Tambunan, 2015, liputan 6.com). 
Indonesia menganut sistem perpajakan self assesment dimana setiap wajib pajak diberikan kewenangan untuk menghitung, melaporkan dan membayar sendiri pajak terhutangnya, maka setiap wajib pajak harus memahami jenis, tata cara penghitungan pajak yang menjadi kewajibannya Disamping itu sistem perpajakan di Indonesia mempunyai tingkat kompleksitas yang tinggi dan cenderung dinamis, mulai dari banyaknya jumlah peraturan hingga perubahan peraturan dari waktu ke waktu yang dilakukan untuk menyesuaikan perkembangan dan pertumbuhan negara Indonesia. Mengamati hal tersebut, maka sangat membutuhkan tenaga kerja yang memahami dan menguasai perpajakan. Kondisi tersebut harus diimbangi dengan penyuluhan yang cukup kepada masyarakat agar pemahaman Wajib Pajak terhadap kewajiban perpajakannya dapat diaplikasikan dengan baik dan benar serta menghindari sanksi perpajakan untuk dapat mengantisipasi tuntutan pangsa kerja saat ini, maka tenaga kerja diberbagai level kompetensi sangat dibutuhkan. Sekolah-sekolah menengah kejuruan yang mengelola berbagai bidang keahlian dengan menggunakan kurikulum yang relevan dan lingk and match dengan tuntutan masyarakat dan ketenagakerjaan Salah satu kompetensi yang diharapkan pada program keahlian Akuntansi adalah kompetensi mengelola administrasi pajak yang diajarkan melalui kompetensi komponen produktif berupa mata diktat perpajakan. Kompetensi utama yang diharapkan dari siswa yang lulus dari jurusan akuntansi ini adalah mampu membuat laporan keuangan serta memahami perpajakan. Walaupun demikian, akuntansi dan perpajakan bukanlah 2 bidang ilmu terpisah, melainkan saling berkaitan. Hal ini akan sangat terasa ketika lulusan SMK yang terlibat dalam dunia usaha, harus memiliki pemahaman di bidang perpajakan dan bagaimana mencatatnya dalam pembukuan perusahaan.

Pelatihan bagi guru-guru SMK/ bidang perpajakan sangat dibutuhkan, mengingat bahwa seperti disebutkan diatas sector pajak merupakan sektor penting sebagai salah satu sumber dana dalam pembiayaan negara dan pembangunan nasional, diharapkan para guru dapat menyebarluaskan pengetahuan dan pemahaman perpajakan kepada siswa nya untuk memahami tentang kewajiban perpajakan secara mendasar dan menyeluruh agar dapat menjalankan kewajiban perpajakan secara benar, lengkap dan jelas termasuk sebagai tambahan informasi bagi para guru-guru agar ilmu/informasi yang diperoleh dalam pelatihan/penyuluhan tersebut dapat disampaikan kepada para siswa dalam proses belajar mengajar di kelas.

Fakultas Ekonomi dan Bisnis Universitas Trisakti adalah sebuah lembaga pendidikan yang melaksanakan kegiatan Tridharma Perguruan Tinggi, yang terdiri dari Pendidikan, Penelitian, dan Pengabdian Kepada Masyarakat (PKM) untuk mencapai visi dan misinya. Peserta kegiatan PKM yang dilaksanakan oleh Fakultas Ekonomi dan Bisnis bermacam-macam, hal ini tergantung dari kebutuhan masyarakat atas ilmu yang mendukung kegiatan mereka, diantaranya adalah guru-guru SMU/SMK, pegawai koperasi, pelaku UKM, serta masyarakat desa lainnya. Tujuan dilakukannya kegiatan Pengabdian Kepada Masyarakat (PKM) adalah sebagai sarana untuk mentransfer pengetahuan yang dimiliki para dosen dan mendapatkan pengalaman dari lapangan untuk meningkatkan pemahaman para dosen.

Kegiatan PKM kali ini adalah hasil kerja sama antara FEB Usakti dengan Lembaga Pengembangan Kompetensi Pendidikan Tenaga Kependidikan dan Kejuruan (P2KPTK2) di wilayah Jakarta Timur, dengan topik yang disampaikan adalah terkait dengan kompetensi guru untuk bidang perpajakan terutama dalam menyelenggarakan pembukuan (Rekonsiliasi Fiskal) menurut ketentuan perpajakan serta menghitung besarnya Pajak Penghasilan Badan guna dapat menjalankan kewajiban perpajakan sesuai dengan ketentuan perpajakan. Tujuan dari kegiatan untuk meningkatkan kompetensi dalam ranah pengetahuan dan ketrampilan guru SMK wilayah Jakarta Timur pada perpajakan khususnya pelaksanaan Rekonsiliasi Fiskal serta penghitungan Pajak Penghasilan ( $\mathrm{PPh})$ Wajib Pajak Badan.

\section{B. METODOLOGI PELAKSANAAN}

Kegiatan PKM ini merupakan kerjasama antara FEB Usakti dengan P2KPTK2 yang sudah beberapa kali dilakukan dengan berbagai topic dan peserta yang berlainan. Tingginya permintaan para guru untuk mendapat pengetahuan lebih dalam mengenai akuntansi dan perpajakan menjadikan kegiatan PKM ini terus dilaksanakan minimal 1(satu) kali dalam 1 (satu) tahun. Kegiatan PKM kali ini dilaksanakan selama 2 (dua) hari, dari tanggal 18 Juli hingga 19 Juli 2019. Peserta merupakan 
para guru-guru akuntansi di SMK/SMU wilayah Jakarta Timur dengan jumlah sebanyak 40 orang. Latar belakang peserta rata-rata adalah para guru-guru SMK/SMU yang kurang memahami secara komprehensi tentang kewajiban perpajakan bagi Wajib Pajak Badan.

Bentuk kegiatan PKM meliputi ceramah dan pelatihan mengenai Pajak Penghasilan Wajib Pajak Badan (PPh badan) serta kertas kerja Rekonsiliasi Fiskal Pemilihan topik ini terkait dengan identifikasi masalah yang terjadi yaitu:

a. Perpajakan merupakan salah satu kompetensi utama SMK Akuntansi karena ilmu perpajakan sangat terkait dengan bidang akuntansi

b. Bidang perpajakan sangat dinamis, ketentuan dan peraturan-peraturan senantiasa berubah mengikuti kebutuhan dan kondisi masyarakat.

Berdasarkan identifikasi masalah tersebut, maka diperlukan pelatihan bagi guru SMK yang mengajar bidang akuntansi untuk memahami lebih dalam mengenai perpajakan khususnya Pajak Penghasilan (PPh) bagi Wajib Pajak Badan dan Rekonsiliasi Fiskal yang dapat dikaitkan dengan pengakuan pendapatan dan beban berdasarkan akuntansi serta berdasarkan peraturan perpajakan. Menurut Pohan (2014), rekonsiliasi fiskal adalah teknik pencocokan yang dilakukan yang dimaksud untuk meniadakan perbedaan antara laporan keuangan komersial (yang disusun berdasarkan prinsip akuntansi/PSAK) dengan peraturan perudang-undangan perpajakan sehingga memunculkan koreksi atau penyesuaian/koreksi fiskal baik koreksi positif maupun negatif, dengan tujuan untuk menentukan jumlah laba usaha fiskal dan besarnya pajak yang terutang.

Kegiatan PKM ini dilakukan secara komprehensif oleh 6 (enam) orang dosen yang memiliki kompetensi di bidang akuntansi dan perpajakan, 3 (tiga) orang mahasiswa, serta beberapa staf Dimaslum FEB Usakti agar kegiatan ini dapat berjalan dengan baik dan tercapainya tujuan yaitu para peserta dapat menyusun kertas kerja Rekonsiliasi Fiskal secara manual, serta dapat menghitung pajak Penghasilan Wajib Pajak Badan sesuai dengan ketentuan perpajakan yang berlaku. Dosen berperan sebagai narasumber untuk materi perpajakan, mahasiswa berperan aktif sebagai asisten narasumber dalam kelas maupun asisten dalam perlengkapan, staf Dimaslum berperan sebagai pihak yang menyiapkan perlengkapan dan peralatan yang mendukung kegiatan ini, serta tim komite PKM FEB Usakti yang bertanggungjawab penuh atas kegiatan ini.

Untuk menunjang pelaksanaan PKM tersebut, maka dilakukan beberapa tahapan:

\section{Tahap persiapan}

Pada tahap ini, panitia PKM dari Fakultas Ekonomi dan Bisnis melakukan pengamatan latar belakang para peserta, dengan mempelajari latar belakang pendidikan peserta, serta kemampuan dan pemahaman peserta dalam penyusunan kertas kerja Rekonsiliasi Fiskal dan Penghitungan Pajak Penghasilan Badan serta pengalaman pengajaran pajak yang sudah pernah dilakukan para guru-guru SMK/SMU serta telah disampaikan kepada anak didik di SMK/SMU.

Berdasarkan hasil pengamatan tersebut, maka diidentifikasi bahwa

a. Para peserta adalah guru Akuntansi di SMK yang sudah memahami tentang akuntansi pada umumnya

b. Masih terdapat beberapa kesalahan dalam pencatatan pajak

c. Para guru-guru SMK/SMU kurang memahami kondisi terkini mengenai perkembangan perpajakan yang ada

Setelah memahami latar belakang tersebut, selanjutnya panitia PKM melakukan persiapan berupa membuatan modul konsep dan latihan, serta menyusun kuisioner yang dibutuhkan untuk melakukan evaluasi, hingga persiapan perlengkapan, peralatan dan ruangan. Panitia melakukan rapat sebanyak 3(tiga) kali untuk persiapan kegiatan ini.

\section{Tahap pelaksanaan}

Kegiatan dilakukan oleh Tim PKM FEB Usakti di Gedung Pertemuan Pengembangan Kompetensi Pendidikan Tenaga Kependidikan dan Kejuruan (P2KPTK2) Jakarta Timur yang berlokasi di Duren Sawit Baru Pondok Bambu Jakarta Timur. 
Bentuk kegiatan adalah ceramah dan pelatihan praktik. Pada hari pertama, sebelum dilakukan pelatihan praktik, peserta terlebih dahulu diberi pemahaman mengenai konsep pajak penghasilan secara umum meliputi subjek pajak penghasilan, objek pajak penghasilan, ruang lingkup biaya dalam pajak penghasilan, tarif pajak penghasilan, serta mekanisme perhitungan pajak penghasilan khususnya wajib pajak badan. Materi diberikan oleh 3 (tiga) orang dosen dan didampingi oleh mahasiswa.

Pada hari kedua,kegiatan dilakukan oleh 3 (tiga) orang dosen lainnya serta mahasiswa sebagai asisten. Materi adalah pemahaman pengakuan pendapatan dan beban menurut Standar Akuntansi Keuangan (SAK) yang berlaku dengan ketentuan peraturan perundang-undangan perpajakan dan tentang cara melakukan pencocokannya. Setelah peserta memahami perbedaan tersebut, kemudian peserta diberikan contoh kasus untuk melakukan rekonsiliasi fiskal (koreksi fiskal positif dan negatif) pada laporan laba rugi perusahaan guna menentukan laba usaha kena pajak. Diakhir kegiatan, peserta diberikan soal kasus mandiri yang dikerjakan para peserta sendiri untuk memahami tingkat kepahaman para peserta.

Berikut ini materi yang disampaikan pada kegiatan PKM selama 2 (dua) hari tersebut.

Tabel 1.

Materi Pajak Penghasilan (PPh) Wajib Pajak Badan dan Rekonsiliasi Fiskal

\begin{tabular}{|c|c|}
\hline Tangggal (waktu) & Materi \\
\hline 18 Juli 2019 ( jam 08.00 & • Konsep Pajak Penghasilan secara umum \\
\hline$-16.00 \mathrm{WIB})$ & $\begin{array}{l}\text { - Konsep Pengakuan pendapatan dan beban menurut SAK } \\
\text { dengan ketentuan perpajakan } \\
\text { - Analisis elemen-elemen penyesuaian guna menentukan } \\
\text { pengaruhnya terhadap laba usaha kena pajak. }\end{array}$ \\
\hline $\begin{array}{l}\text { 19 Juli } 2019 \text { ( jam } 08.00 \\
-16.00 \text { WIB) }\end{array}$ & $\begin{array}{l}\text { - Pratik: Menyesuaikan atau mengoreksi fiskal (koreksi } \\
\text { fiskal positif dan negatif). } \\
\text { - Praktik: Menyusun laporan keuangan fiskal } \\
\text { - Latihan kasus mandiri }\end{array}$ \\
\hline
\end{tabular}

Sumber: data diolah
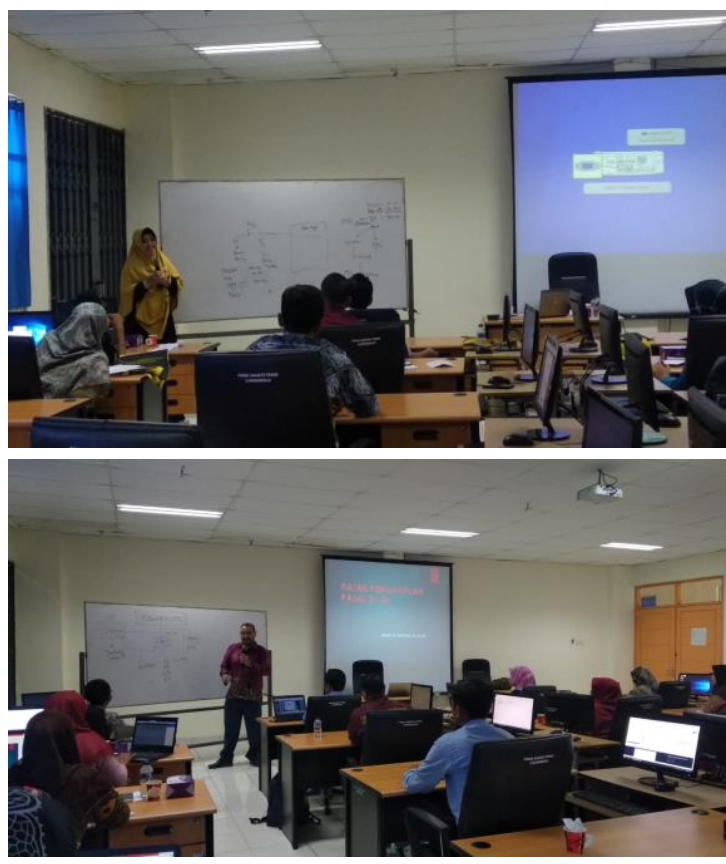

Gambar 1. Foto Kegiatan

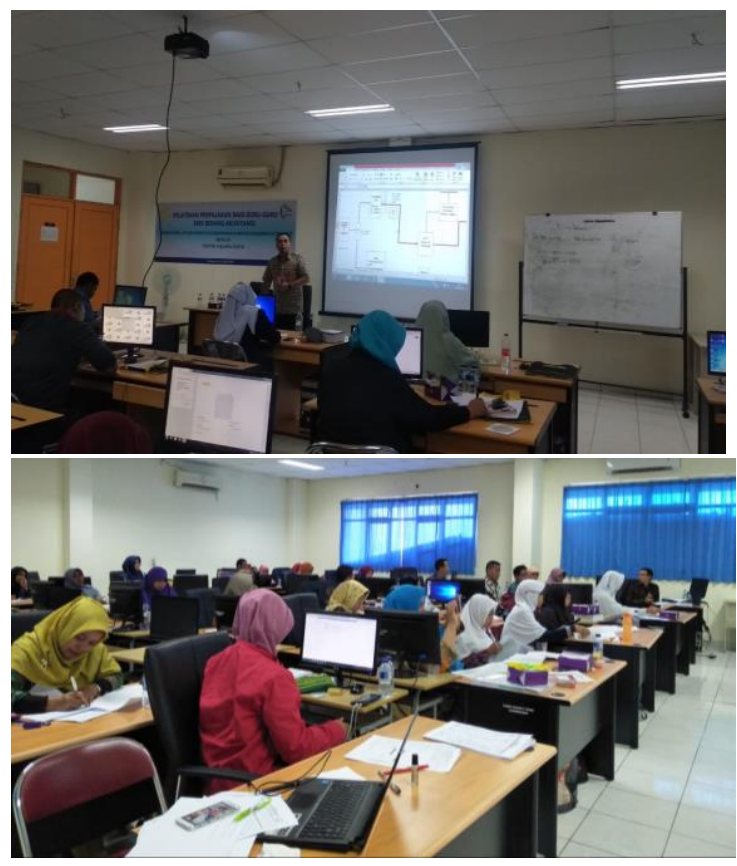



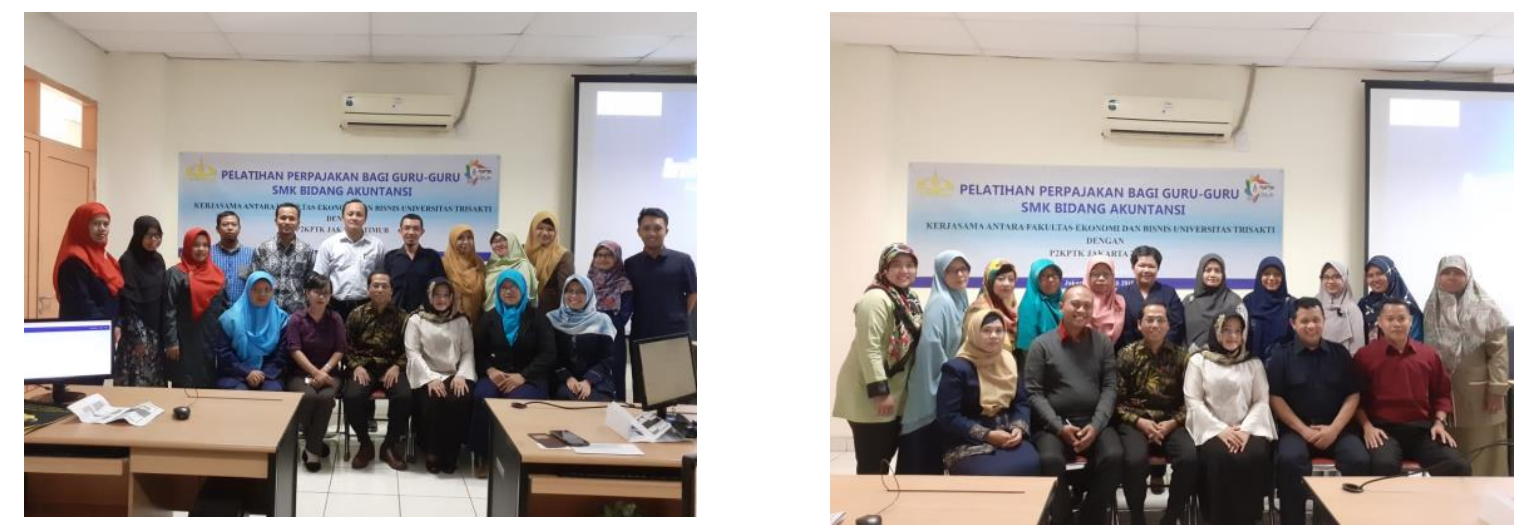

Sumber: Laporan PKM FEB Usakti

\section{Tahap Evaluasi}

Pada tahap ini dilakukan penyebaran kuisioner kepada para peserta dengan pertanyaan-pertanyaan yang terakait dengan kegiatan PKM, dengan tujuan agar dapat mengetahui kualitas dan pencapaian dari hasil pelatihan ini sehingga segala kekurangan kegiatan ini dapat diperbaiki dan mempertahankan kelebihannya. Pada tahap ini, disamping kuisinoner yang disebar, para peserta juga diberikan soal kasus yang dikerjakan mandiri terkait dengan materi PKM, sehingga pelaksana pkm dapat mengetahui perkembangan kompetensi para peserta sebagai hasil dari kegiatan ini.

\section{HASIL DAN PEMBAHASAN}

Tujuan kegiatan PKM ini adalah untuk meningkatkan kompetensi peserta yaitu para guru smk di lingkup Pengembangan Kompetensi Pendidikan Tenaga Kependidikan dan Kejuruan (P2KPTK2) di wilayah Jakarta Timur. Berdasarkan hasil penilaian dosen pelaksana PKM yang diperoleh dari pengamatan, kuisioner,tanya jawab serta penyelesaian studi kasus yang dilakukan para guru, maka diperoleh hasil kesimpulan dari para pelaksana kegiatan seperti tergambar pada grafik 1 dibawah ini

\section{Grafik 1. Perubahan kompetensi Guru sebelum dan setelah Pelatihan}

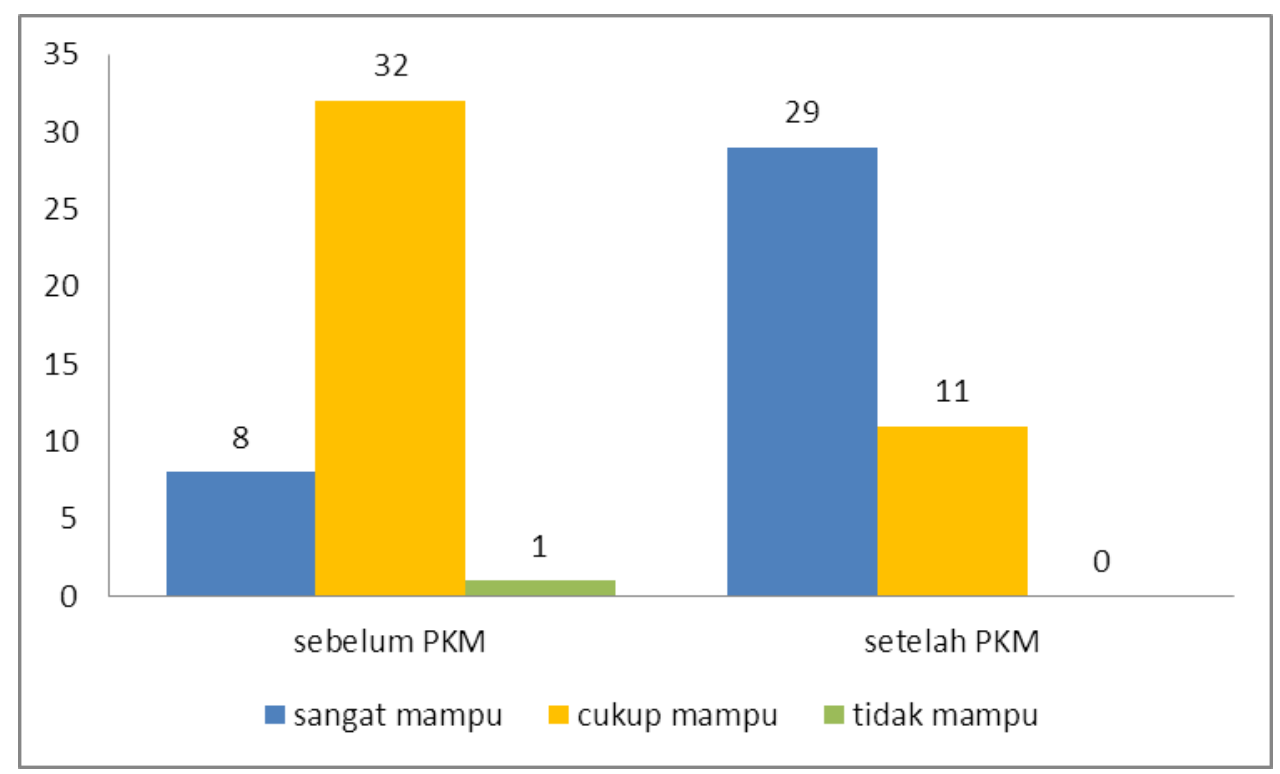

Sumber : data diolahBerdasarkan grafik tersebut terlihat bahwa, sebelum dilaksanakan pelatihan masih ada guru yang belum mampu menyelesaikan kasus laporan rekonsiasi fiskan, dan hanya $20 \%$ guru yang sangat mampu melaksanakannya. Terlihat pada grafik tersebut, setelah dilaksanakan pelatihan PKM ini, kemampuan guru atau kompetensi guru di bidang perpajakan khususnya dalam 
penyusunan laporan rekonsiasi fiscal meningkat, terlihat bahwa $70 \%$ peserta memahami pajak penghasilan dan mampu melakukan rekonsiliasi fiskal.

Disamping itu, pada akhir sesi kegiatan PKM, tim PKM menyebarkan kuisioner dan melakukan analisa atas pelaksanaan kegiatan ini. Berdasarkan analisa tersebut, maka ditemukan beberapa kelebihan dan kelemahan yang dapat menjadi masukan untuk kegiatan PKM berikutnya

Tabel 2

Hasil Kegiatan PKM

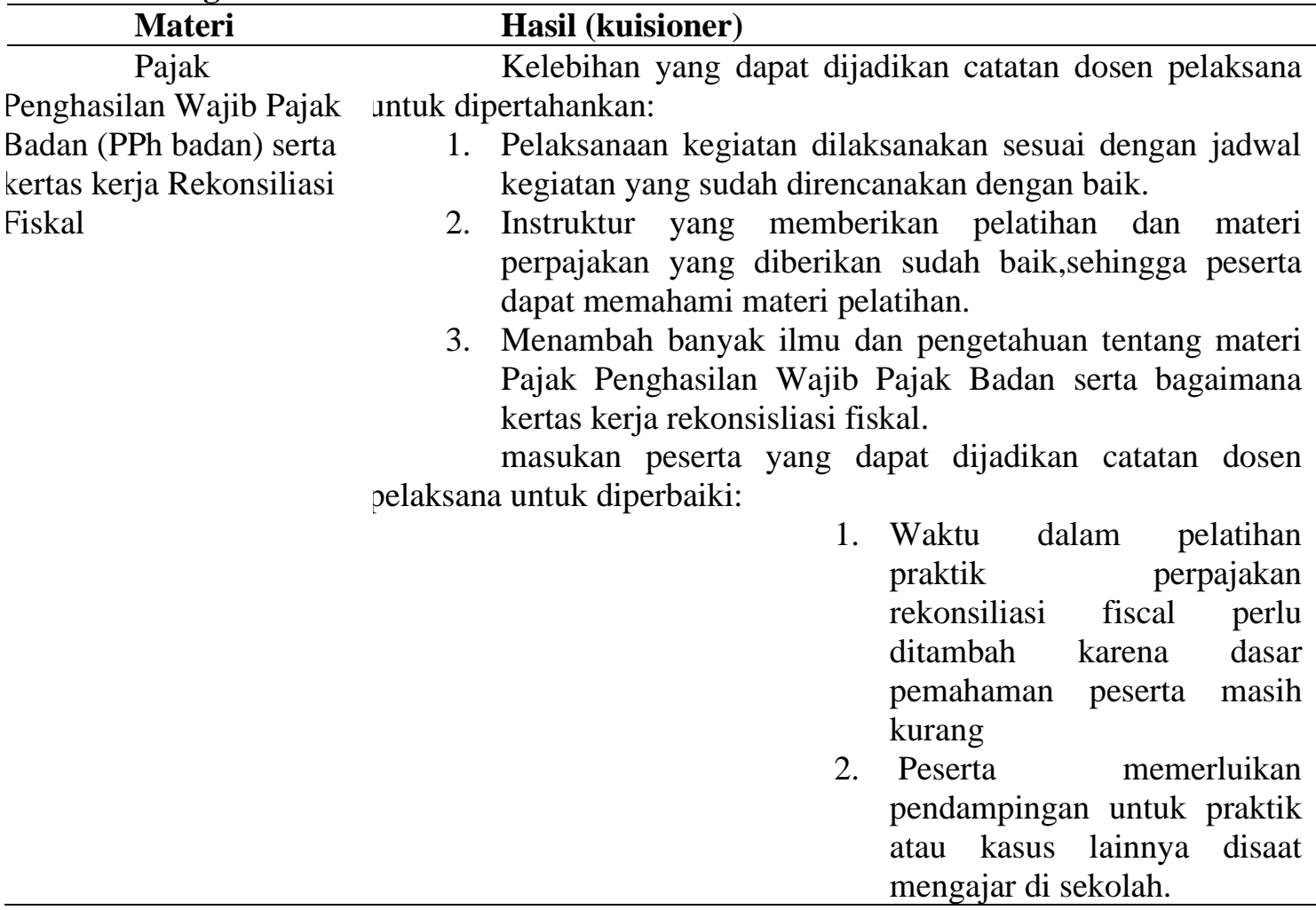

Sumber: data diolah

Berdasarkan tabel 2 diatas, terlihat bahwa, para guru merasakan manfaat dari pelatihan pajak ini. Para Guru SMK dapat lebih memahami tentang pelaksanaan Rekonsiliasi Fiskal menurut ketentuan perpajakan serta menghitung besarnya Pajak Penghasilan Badan pelaksanaan kewajiban perpajakan dengan baik dan benar, sesuai ketentuan perpajakan yang berlaku sebagai salah satu bahan pengajaran bagi peserta didiknya di lingkungan sekolahnya masing-masing.

\section{KESIMPULAN DAN SARAN}

Berdasarkan pemaparan di atas, dapat disimpulkan bahwa secara garis besar pelaksanaan kegiatan pelatihan perpajakan khususnya mengenai penyusunan laporan rekonsiliasi fiskal sebagai dasar untuk penghitungan Pajak Penghasilan (PPh) bagi Wajib Pajak Badan Bagi Guru dan Pengajar SMK di lingkungan Pengembangan Kompetensi Pendidikan Tenaga Kependidikan dan Kejuruan (P2KPTK2) wilayah Jakarta Timur dapat berjalan dengan baik. Hasil kegiatan ini dapat meningkatkan kompetensi guru peserta kegiatan, dengan terlihat dari hasil sebagian besar peserta dapat menyelesaikan soal kasus mandiri yang dilakukan oleh para guru dengan baik dan benar.

Kegiatan PKM ini sangat bermanfaat bagi guru SMK, khususnya guru pengajar mata kuliah akuntansi, mengingat kurikulum akuntansi yang tidak hanya mengajarkan akuntansi secara umum, namun juga mengajarkan ilmu perpajakan. Peserta sangat mengharapkan pelatihan ini dilaksanakan rutin dan berkesinambungan dengan pendampingan para dosen diluar kegiatan PKM. Disamping itu, kegiatan PKM ini juga bermanfaat bagi Fakultas Ekonomi dan Bisnis Universitas Trisakti, khususnya bagi dosen dan mahasiswa pelaksana, karena dengan adanya kegiatan Pengabdian Kepada Masyarakat 
(PKM), para dosen dan mahasiswa dapat berbagi ilmu dan pengalaman dengan para peserta sehingga dapat semakin memahami pelaksanaan Rekonsiliasi Fiskal menurut ketentuan perpajakan serta menghitung besarnya Pajak Penghasilan Badan pelaksanaan kewajiban perpajakan.

\section{DAFTAR PUSTAKA}

IAI, 2017, Standar Akuntansi Keuangan,

Pohan, Chairil Anwar. 2014. Pembahasan Komprehensif Perpajakan Indonesia Teori dan Kasus. Jakarta : Mitra Wacana Media.

Resmi,Siti. 2013. Perpajakan Teori dan Kasus. Salemba Empat. Jakarta

Tambunan Rustom 2015, Mengupas Sunset Policy dan Tax Amnesti, strategi mengejar Target Pajak, https://www.liputan6.com/bisnis/read/2217599/mengupas-sunset-policy-amp-tax-amnestysenjata-kejar-target-pajak 